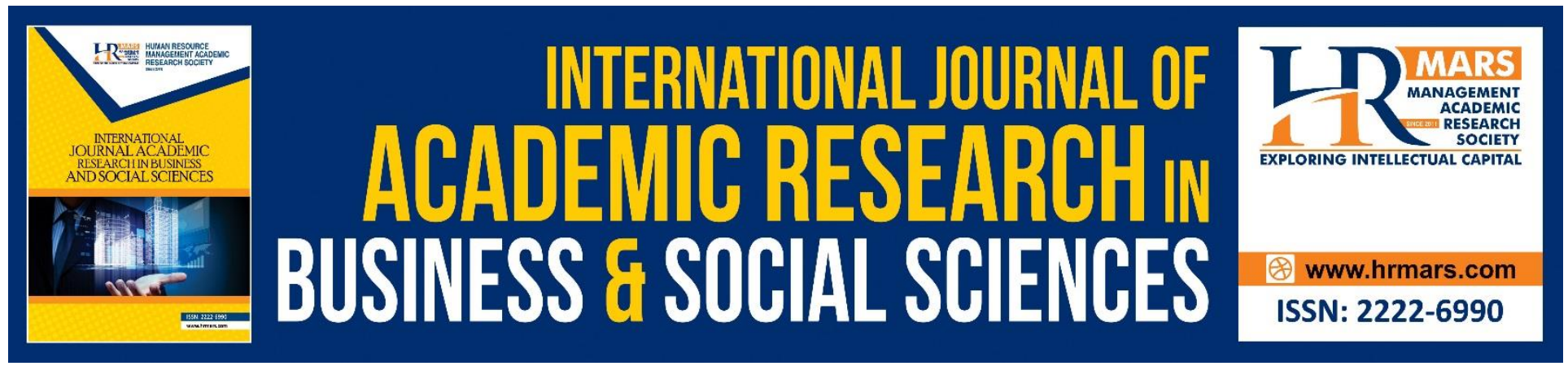

\title{
Intellectual Capital of Malaysian Banks
}

\author{
Alim Dee, Rossazana Ab-Rahim \& Noor Shazreen Mortadza
}

To Link this Article: http://dx.doi.org/10.6007/IJARBSS/v9-i6/6032

DOI: $10.6007 /$ IJARBSS/v9-i6/6032

Received: 18 April 2019, Revised: 19 May 2019, Accepted: 07 June 2019

Published Online: 30 June 2019

In-Text Citation: (Dee, Ab-Rahim, \& Mortadza, 2019)

To Cite this Article: Dee, A., Ab-Rahim, R., \& Mortadza, N. S. (2019). Intellectual Capital of Malaysian Banks. International Journal of Academic Research in Business and Social Sciences, 9(6), 774-785.

Copyright: (C) 2019 The Author(s)

Published by Human Resource Management Academic Research Society (www.hrmars.com)

This article is published under the Creative Commons Attribution (CC BY 4.0) license. Anyone may reproduce, distribute, translate and create derivative works of this article (for both commercial and non-commercial purposes), subject to full attribution to the original publication and authors. The full terms of this license may be seen

at: http://creativecommons.org/licences/by/4.0/legalcode

\section{Vol. 9, No. 6, 2019, Pg. $774-785$}

Full Terms \& Conditions of access and use can be found at http://hrmars.com/index.php/pages/detail/publication-ethics 


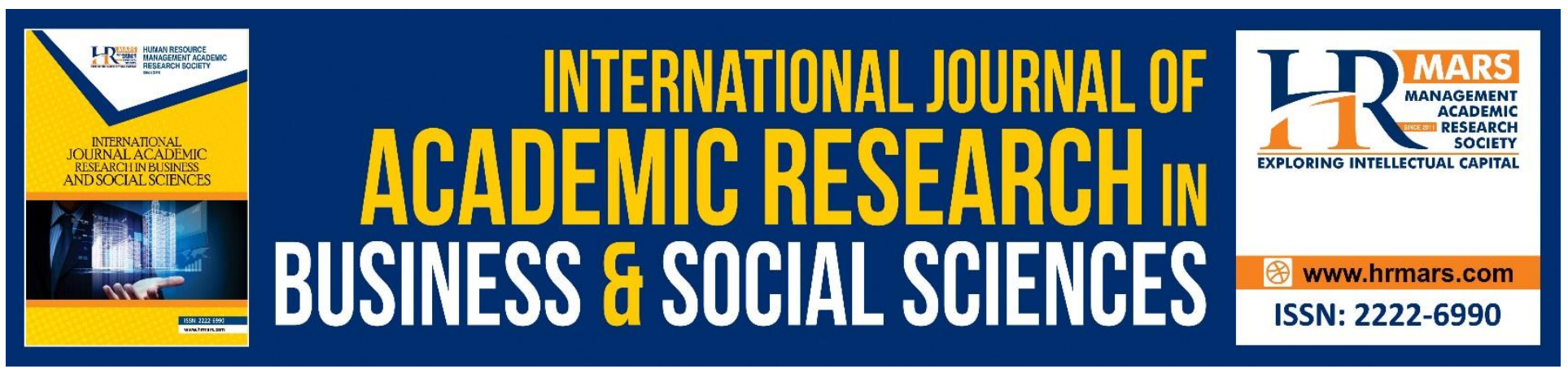

\title{
Intellectual Capital of Malaysian Banks
}

\author{
Alim Dee, Rossazana Ab-Rahim \& Noor Shazreen Mortadza \\ Faculty of Economics \& Business, Universiti Malaysia Sarawak, Malaysia. \\ Email: arrossazana@unimas.my
}

\begin{abstract}
The importance of intellectual capital has induced drastic movement in conducted of businesses by switching from traditional labour to knowledge labour whereby to compete with the incumbents and the newcomers. On this note, services sector especially banking industry plays a vital role in the development of economies that affected overall in gross domestic product compared to the other production sectors thus intellectual capital is important to the growth of banking sector in a nation. Therefore, the general objective of this study is to investigate the intellectual capital of Malaysian banks over the study period of 2007 to 2016 by employing Model of Value Added Intellectual Coefficient (VAIC). In view of the above scenarios, the specific objectives of this study is to investigate the sources of intellectual capital namely human capital efficiency (HCE), structural capital efficiency (SCE) and capital employed efficiency (CEE) of the Malaysian banking institution. The results of this study show that human capital efficiency is the most influential components in the intellectual capital among Malaysian banks. Thus, the findings of this study recommend on the bank's management and policy makers to increase on the efforts to encourage the utilizing in human capital which is treated as an effective alternatives in creating bank's value as well as consider the human capital as a single resources of the intellectual capital in improving on the efficiency performance of the banks.
\end{abstract}

Keywords: Intellectual Capital, Malaysian Bank, VAIC Model

\section{Introduction}

Advancements in the information or knowledge economy has created a great impact on the increasing level of awareness and responsiveness on the importance of intellectual capital nationwide (Guthrie, 2001). However, the future benefits would only be loss if there is an existent of any ignorance and underestimation on intellectual capital (Roslender \& Fincham, 2004). The evolution of the phases of social-economy has been proven based on the hierarchies among production factors which typically vary from one another. Beginning of the 1980s until present, the information society has started to develop with the world witnessing transformations and advancements in Information and Communication Technology (ICT) which thus changed the mechanism for the creation of wealth to be derived from labour, capital, natural resources, and entrepreneurship. In short, the efficient use of intellectual capital or intangible assets progressively gained a significant role in terms of the firms' performance. In fact, this transformation attached to 
knowledge, information technologies, and intellectual capital has shown to be extremely pivotal in producing wealth (Marti, 2000). Nevertheless, Steward (1997) positively believes the traditional economy of capitals such as machinery, land and labour have been substituted with the current knowledge-based paradigm, whereby an old characters is becoming irrelevant in guaranteeing the production of wealth (Chen et al., 2005). Additionally, Drucker (1993) claims knowledge is the type of resources attached with the traditional factors of production and absolutely meaningful resources today (Bontis, 2001; Pulic, 2004) while the traditional factors of production served as secondary (Kozak, 2011). In this vein, most developing countries have started to transform on their economic systems to be based on knowledge economy since the knowledge act as an engine for the development in economic growth (Sengge, 2010). Align with the significant roles of intellectual capital which have clearly fostered the economic growth, (Stahle \& Bonfour, 2008) therefore, the subject is treated as the major national investment that could support the national economic performance (Bismuth \& Tojo, 2008).

Notwithstanding, intellectual capital has drawn a little concerned from the numerous industries, especially within the knowledge-based intensive sectors. One of the sectors that are heavily involved in the exercising and establishing of intellectual capital is the banking and financial services sector while the banking sector has the highest tendency of being subjects to the enthusiastic setting of this study. Banks are relatively more competitive within the market and being extremely influences from the globalized environment that forced the industry to be reshaped into the knowledge-intensive industry. Pulic (2004) suggests the relationship between intellectual capital and successful corporate performance is found to be positively strong and revealed the importance of intellectual capital through the sample among the Australian banking sector. Thus, it is particularly vital to identify the basic roles as well as the implications of the intellectual capital towards the advancement of the banking industry (Belkaoui, 2003; Goh, 2005; Najibullah, 2005; Saengchan, 2008).Therefore, the study is aims to investigate the Value Added Intellectual Coefficient (VAIC) and the main sources of VAIC components namely human capital efficiency, structural capital efficiency, and capital employed efficiency. The remaining of this paper is consists of sections that dealing with empirical studies of intellectual capital as presented under Past Studies section follows by Data and Methodology section. The subsequent section presents on results and the discussion of the results while the Conclusion sections offer a summary of the results as well the policy implications.

\section{Past Studies}

Edvinsson and Sullivan (1996) has define the intellectual capital as information that include values. However, the definition has been broadened and modest which refer to a combination of knowledge, experience, organizational, technology, customer relationship and professional skills for achieving on the real competitive edge within the market (Edvinsson \& Malone, 1997). Steward (1997) suggests intellectual capital are extremely useful and full of information whereby information is describe the knowledge, information, technologies, skills, expertise, intellectual property, customer loyalty and team management in contributing and creating values within the organization. Steward (1997) has further classified the intellectual capital into three major components namely human capital, structural capital and customer or relational capital. Mohiuddin et al., (2006) describe main 
characteristics of human capital that basically owned by individual or employee; however, the organizations owned the information by structuring on the procedures and system format only. Furthermore, Roos and Roos (1997) and Zeghal and Maaloul (2010) refer to the human capital indicate on employees' knowledge, experiences, and skills which will only be gone when they leave the organization since the human capital connected with employees' capabilities such as competencies, commitments, motivations, loyalty, and other similar attributes. Meanwhile, for the structural capital, Ashton (2005) suggest the various types including both internal and external of value drivers. The former refer to organizations that involved in the processes, routines, databases, and organizational structures, while the latter is refer to relationships with customers, suppliers and alliance partners (Appuhami, 2007). An organization that applied the strong structural capital tend to more developed in supportive the corporate cultures among its employees in attempting and exercising the new things at their workplace (Bontis et al., 2000). Prahalad and Ramaswamy (2000) indicate that customers are normally subject to reflect the firm's performance. Basically, the concept of customer capital or social capital has connected or linked to the social and interpersonal factors (Porters, 1998) between individuals or societies (Kale et al., 2000).

Sledzik (2013) who investigate intellectual capital performance among the Polish bank by measuring the level of intangible resources within the sector. The data collected within the period of 2005 until 2009 and calculated based on the formula given by VAIC model in measuring the intellectual capital efficiency. Findings revealed and argued that intellectual capital technically depends heavily on the human capital efficiency, thus has suggested that investments in human capital will provide security in creating high value added in futures rather investments in both structural capital and capital employed efficiency. Another recent empirical study conducted by Isanzu (2016), on the relationship between intellectual capital and financial performance of banks in Tanzania. The sample data collected from 6 banks within the study of period from 2010 until 2013. Thus resulted evidence that intellectual capital is highly connected and provide the positive impact towards the performance of Tanzanian banks.

\section{Data and Methodology}

The sample for the study consists of all the Malaysian Islamic and Conventional banks currently registered with a full licenses listed under Bank Negara Malaysia (BNM). According to the final list, there are only 16 Islamic and 27 Conventional banks that operated in Malaysia as of year 20017. In line with the data, the length of study has been selected for the 10-years period starting from the financial year ending 2007 until the financial year ending 2016. Whereby, 10 years period is assumed to be long enough for handling any short-term irregularities and provide reliable estimates of the banks' intellectual capital while those data is obtained from annual report of the respective Islamic and Conventional banks.

The traditional way of ranking on the Malaysian banks will render by comparing according to the sum of total VAIC scored from the highest to the lowest scored. Edvinsson and Malone (1997), the value are consists of capital employed (i.e., financial and physical capital) and intellectual capital namely refer to human capital and structural capital. In accordance with VAIC framework, the information for value creation efficiency on both physical and intellectual capital of the company will also be 
computed (Tan et al., 2007). Therefore, VAIC model is not to measure intellectual capital only but it also the company's efficiency as a whole (Mohiuddin et al., 2006). Basically, VAIC model is treated as analytical procedures that formally design for the purpose of management, shareholders and other relevant stakeholders to monitor and evaluate the efficiency of Value Added (VA) from the total resource (Company) through the major components of intellectual capital (Firer \& Williams, 2003). Based on Pulic and Bornemann, (1997), the VAIC model offer the easiest way in measuring on the idea of intellectual capital. Main reason is due to the reliable and availability of the data can be obtain from the company's annual report (Mavridis, 2004). In fact, study on intellectual capital within banking line is encouraging in which the bank's staff within this sector are homogeneous supported with the sector that are intellectually intensive in nature. (Kubo \& Saka, 2002).

\section{Measurement of Intellectual Capital}

Previous studies such as Bontis (1998), Chen, et al., (2005), Tayles et al., (2007) and Stahle et al., (2011) acknowledged the importance of intellectual capital which has been previously accepted. Likewise, Chen et al., (2005) and Tan et al., (2007) postulated that the measurement of intellectual capital however still under the preliminary stage of development. Basically, the actual and accurate techniques that can be used to determine intellectual capital are to be based on underlying theories of intellectual capital which have not yet to be evolved. The VAIC measures the creation of value per money unit invested in each sources. Hence, the formula as follow:

VA = Operating Profit + Employee Costs + Depreciation + Amortization

Where:

$V A=I$ (total interest expenses) $+\mathrm{DP}$ (depreciation expenses) $+\mathrm{D}$ (dividends) $+\mathrm{T}$ (corporate tax) $+\mathrm{R}$ (profit retain for the year)

Indicator for Human Capital Efficiency (HCE)

Where:

$$
\mathrm{HCE}=\mathrm{VA} / \mathrm{HC}
$$

$\mathrm{VA}=$ Value added

$\mathrm{HC}=$ Total employee expenses (personnel cost/salaries and wages-considered as investment

Indicator of Structural Capital Efficiency (SCE)

\section{SCE $=$ VA/HC}

Where:

$\mathrm{SC}=\mathrm{VA}-\mathrm{HC}$

$\mathrm{HC}=$ Total Salaries and wages for a company

Indicator of Capital Employed Efficiency

Where:

$$
\mathrm{CEE}=\mathrm{VA} / \mathrm{CE}
$$

$\mathrm{CE}=$ Physical Assets + Financial Asset $=$ total asset - intangible asset 
INTERNATIONAL JOURNAL OF ACADEMIC RESEARCH IN BUSINESS AND SOCIAL SCIENCES

Vol. 9, No. 6, June, 2019, E-ISSN: 2222-6990 @ 2019 HRMARS

\section{$V A I C=C E E+H C E+S C E$}

\section{Discussion of the Results}

The results shows on Table 1.1 has demonstrated on the findings for Malaysian Islamic Banks indicated that the Maybank Islamic Bhd was revealed as the top performance among all Islamic banks with the highest average of total scoring of VAIC at 47.1791, followed by the Public Islamic Bank Bhd with total average VAIC scoring of 35.4844 and ranked as second position. The third ranked was under AmIslamic Bank Bhd with an average total of VAIC scoring at 33.7364 from 2007 until 2016. In contrast, Al-Rajhi Banking \& Investment (M) Bhd, Kuwait Finance Bank (M) Bhd and the Asian Finance (M) Bank Bhd were the lowest average of VAIC scoring among all Islamic banks that recorded only at $1.1041,1.2616$ as well as at 1.3532 respectively. Basically, being an efficient alone is not consider as inefficient as the bank must be able to create values hence in the case of ranking for the value added scoring, it has shown that the Asian Finance Bank Bhd were listed on the highest value added with total average of value added at RM23, 101,004 while Maybank Islamic Bhd recorded at RM814, 289.33. As seen, the foreign Islamic banks namely HSBC Amanah (M) Bhd has denominated on the highest VAIC scored for Malaysian Islamic banks with total average of VAIC scored at 15.6571.Other ranking on the Islamic banks are illustrated listed under Table 1.1. 
INTERNATIONAL JOURNAL OF ACADEMIC RESEARCH IN BUSINESS AND SOCIAL SCIENCES Vol. 9, No. 6, June, 2019, E-ISSN: 2222-6990 @ 2019 HRMARS

Table 1.1: VAIC and VA Rank for Malaysian Islamic Bank (2007-2016)

\begin{tabular}{|c|c|c|c|c|c|c|c|}
\hline ISLAMIC BANKS & HCE & SCE & CEE & VAIC & $V A(R M)$ & $\begin{array}{l}\text { VAIC } \\
\text { RANK }\end{array}$ & $\begin{array}{l}\text { VA } \\
\text { RAN } \\
K \\
\end{array}$ \\
\hline MAYBANK ISLAMIC & 46.190 & 0.978 & 0.010 & 47.179 & $814,289$. & 1 & 3 \\
\hline BHD & 2 & 0 & 8 & 1 & 33 & & \\
\hline PUBLIC ISLAMIC BANK & 34.498 & 0.970 & 0.014 & 35.484 & 527,521 & 2 & 4 \\
\hline BHD & 8 & 8 & 7 & 4 & 67 & & \\
\hline AMISLAMIC BANK BHD & $\begin{array}{l}32.754 \\
3\end{array}$ & $\begin{array}{l}0.967 \\
9\end{array}$ & $\begin{array}{l}0.014 \\
2\end{array}$ & $\begin{array}{l}33.736 \\
4\end{array}$ & $\begin{array}{l}270,986 \\
70\end{array}$ & 3 & 8 \\
\hline HSCB AMANAH BANK & 14.797 & 0.845 & 0.014 & 15.657 & 172,285 . & 4 & 10 \\
\hline BHD & 3 & 3 & 5 & 1 & 38 & & \\
\hline HONG LEONG ISL. & 11.304 & 0.907 & 0.012 & 12.224 & 200,904 & 5 & 9 \\
\hline BANK BHD & 3 & 9 & 4 & 6 & 80 & & \\
\hline $\begin{array}{l}\text { CIMB ISLAMIC BANK } \\
\text { BHD }\end{array}$ & 8.5713 & $\begin{array}{l}0.839 \\
6\end{array}$ & $\begin{array}{l}0.011 \\
9\end{array}$ & 9.4228 & $\begin{array}{l}520,230 . \\
89\end{array}$ & 6 & 5 \\
\hline STAN CHART.SADIQ (M) & 8.1716 & 0.815 & 0.007 & 8.9940 & $48,835.6$ & 7 & 16 \\
\hline $\mathrm{BHD}$ & & 0 & 4 & & 7 & & \\
\hline $\begin{array}{l}\text { RHB ISLAMIC BANK } \\
\text { BHD }\end{array}$ & 5.7129 & $\begin{array}{l}0.773 \\
3\end{array}$ & $\begin{array}{l}0.012 \\
9\end{array}$ & 6.4991 & $\begin{array}{l}276,372 . \\
80\end{array}$ & 8 & 7 \\
\hline $\begin{array}{l}\text { OCBC AL-AMIN (M) } \\
\text { BANK HD }\end{array}$ & 3.4685 & $\begin{array}{l}0.830 \\
8\end{array}$ & $\begin{array}{l}0.011 \\
3\end{array}$ & 4.3106 & $\begin{array}{l}109,935 . \\
89\end{array}$ & 9 & 13 \\
\hline $\begin{array}{l}\text { AFFIN ISLAMIC.BANK } \\
\text { BHD }\end{array}$ & 3.5647 & $\begin{array}{l}0.400 \\
7\end{array}$ & $\begin{array}{l}0.015 \\
3\end{array}$ & 4.2014 & $\begin{array}{l}139,697 . \\
60\end{array}$ & 10 & 12 \\
\hline BANK ISLAM (M) BHD & 2.5192 & $\begin{array}{l}0.601 \\
5\end{array}$ & $\begin{array}{l}0.197 \\
6\end{array}$ & 3.3183 & $\begin{array}{l}922,760 . \\
50\end{array}$ & 11 & 2 \\
\hline $\begin{array}{l}\text { ALLIANCE ISLAMIC B. } \\
\text { BHD }\end{array}$ & 2.4867 & $\begin{array}{l}0.582 \\
7\end{array}$ & $\begin{array}{l}0.020 \\
9\end{array}$ & 3.0903 & $\begin{array}{l}142,905 \\
71\end{array}$ & 12 & 11 \\
\hline $\begin{array}{l}\text { BANK MUAMALAT (M) } \\
\text { BHD }\end{array}$ & 1.9542 & $\begin{array}{l}0.479 \\
5\end{array}$ & $\begin{array}{l}0.017 \\
0\end{array}$ & 2.4508 & $\begin{array}{l}319,821 . \\
80\end{array}$ & 13 & 6 \\
\hline $\begin{array}{l}\text { ASIAN FIN (M) BANK } \\
\text { BHD }\end{array}$ & 1.1880 & $\begin{array}{l}0.155 \\
1\end{array}$ & $\begin{array}{l}0.010 \\
2\end{array}$ & 1.3532 & $\begin{array}{l}23,101,0 \\
04\end{array}$ & 14 & 1 \\
\hline $\begin{array}{l}\text { KUWAIT FIN HOUSE } \\
\text { (M) BHD }\end{array}$ & 0.6243 & $\begin{array}{l}0.630 \\
1\end{array}$ & $\begin{array}{l}0.007 \\
2\end{array}$ & 1.2616 & $\begin{array}{l}62,360.2 \\
0\end{array}$ & 15 & 15 \\
\hline $\begin{array}{l}\text { AL-RAJHI BANK \& INVST } \\
(\mathrm{M})\end{array}$ & 1.0555 & $\begin{array}{l}0.038 \\
2\end{array}$ & $\begin{array}{l}0.010 \\
4\end{array}$ & 1.1041 & $\begin{array}{l}77,522.4 \\
0\end{array}$ & 16 & 14 \\
\hline
\end{tabular}

As oppose to the Islamic banks, Table 1.2 has shown on the findings for Malaysian Conventional banks and according to the previous studies done such as Goh (2005) and Nik Maheran et al., (2009) identifying the Public Bank Bhd as the pioneer for Malaysian Conventional banks that indicate the bank fully optimize on their intellectual capital efficiently hence, for the current study provide the similar finding that revealed the same banks namely Public Bank Bhd was still on the top ranking and 
INTERNATIONAL JOURNAL OF ACADEMIC RESEARCH IN BUSINESS AND SOCIAL SCIENCES Vol. 9, No. 6, June, 2019, E-ISSN: 2222-6990 @ 2019 HRMARS

maintain their highest average of VAIC scoring at 5.9883 from the year 2007 until 2016. Following that, the Bank of Nova Scotia (M) Bhd and Bank of Tokyo-Mitsubishi UFJ (M) Bhd were the $2^{\text {nd }}$ and $3^{\text {rd }}$ ranked with their average VAIC scoring at 5.7928 and 5.6062 respectively.

Table 1.2: VAIC and VA Rank for Malaysian Conventional Banks (2007-2016)

\begin{tabular}{|c|c|c|c|c|c|c|c|}
\hline CONVENTIONAL BANKS & $H C E$ & SCE & CEE & VAIC & $V A(R M)$ & $\begin{array}{l}\text { VAIC } \\
\text { ANK }\end{array}$ & VA NK \\
\hline PUBLIC BANK BHD & 5.1577 & 0.8038 & 0.0269 & 5.9883 & 6075755.70 & 1 & 2 \\
\hline $\begin{array}{l}\text { BANK OF NOVA SCOTIA } \\
\text { (M) B. }\end{array}$ & 5.0072 & 0.7665 & 0.0191 & 5.7928 & 82638.40 & 2 & 18 \\
\hline $\begin{array}{l}\text { BANK OF TOKYO- } \\
\text { MITSUB (M) B }\end{array}$ & 4.8055 & 0.7790 & 0.0217 & 5.6062 & 260860.56 & 3 & 14 \\
\hline $\begin{array}{l}\text { DEUTSCHE BANK (M) } \\
\text { BHD }\end{array}$ & 3.7256 & 0.7077 & 0.0187 & 4.4520 & 217790.70 & 4 & 15 \\
\hline $\begin{array}{l}\text { UNITED OVERSEAS } \\
\text { BANK (M) B }\end{array}$ & 3.5210 & 0.7142 & 0.0224 & 4.2576 & 1556421.80 & 5 & 8 \\
\hline $\begin{array}{l}\text { BANK OF CHINA (M) } \\
\text { BHD }\end{array}$ & 3.3266 & 0.6947 & 0.0201 & 4.0415 & 97300.60 & 6 & 16 \\
\hline $\begin{array}{l}\text { SUMITOMO-MITSUI } \\
\text { BANK (M) B }\end{array}$ & 3.3488 & 0.6761 & 0.0152 & 4.0401 & 68950.80 & 7 & 20 \\
\hline $\begin{array}{l}\text { HONG LEONG BANK } \\
\text { BHD }\end{array}$ & 3.3230 & 0.6933 & 0.0201 & 4.0364 & 2320933.60 & 8 & 5 \\
\hline CITIBANK (M) BHD & 3.2886 & 0.6897 & 0.0304 & 4.0087 & 1241589.90 & 9 & 10 \\
\hline HSBC BANK (M) BHD & 3.1735 & 0.6825 & 0.0289 & 3.8849 & 1819692.90 & 10 & 7 \\
\hline MAYBANK BHD & 2.9843 & 0.6353 & 0.0230 & 3.6426 & 7856531.10 & 11 & 1 \\
\hline AMBANK BHD & 2.8622 & 0.6447 & 0.0252 & 3.5321 & 2181793.80 & 12 & 6 \\
\hline OCBC BANK (M) BHD & 2.8346 & 0.6336 & 0.0252 & 3.4934 & 1533581.60 & 13 & 9 \\
\hline ALLIANCE BANK BHD & 2.8099 & 0.6286 & 0.0236 & 3.4621 & 784632.00 & 14 & 13 \\
\hline RHB BANK BHD & 2.8029 & 0.6353 & 0.0218 & 3.4600 & 2790125.10 & 15 & 4 \\
\hline $\begin{array}{l}\text { STANDARD CHARTERED } \\
\text { (M) B }\end{array}$ & 2.8361 & 0.5961 & 0.0209 & 3.4532 & 945892.80 & 16 & 11 \\
\hline AFFIN BANK BHD & 2.7892 & 0.7723 & 0.0207 & 3.4259 & 818340.00 & 17 & 12 \\
\hline CIMB BANK BHD & 2.6670 & 0.6216 & 0.0241 & 3.3128 & 5127791.80 & 18 & 3 \\
\hline $\begin{array}{l}\text { JP MORGAN CHASE (M) } \\
\text { BHD }\end{array}$ & 2.6472 & 0.5620 & 0.0165 & 3.2257 & 87442.44 & 19 & 17 \\
\hline $\begin{array}{l}\text { BANK OF AMERICA (M) } \\
\text { BHD }\end{array}$ & 2.5932 & 0.5543 & 0.0213 & 3.1687 & 50853.43 & 20 & 22 \\
\hline $\begin{array}{l}\text { BANGKOK BANK (M) } \\
\text { BHD }\end{array}$ & 2.2110 & 0.4704 & 0.0129 & 2.6943 & 40223.20 & 21 & 24 \\
\hline $\begin{array}{l}\text { ROYAL BANK OF SCOTL. } \\
\text { (M) B }\end{array}$ & 2.1441 & 0.4458 & 0.0157 & 2.6056 & 70862.30 & 22 & 19 \\
\hline
\end{tabular}


INTERNATIONAL JOURNAL OF ACADEMIC RESEARCH IN BUSINESS AND SOCIAL SCIENCES Vol. 9, No. 6, June, 2019, E-ISSN: $2222-6990$ @ 2019 HRMARS

\begin{tabular}{l|ccccccc}
$\begin{array}{l}\text { INDST. AND COMM } \\
\text { BANK (M) B }\end{array}$ & 1.9425 & 0.4720 & 0.0107 & 2.4252 & 54285.57 & 23 & 21 \\
$\begin{array}{l}\text { NATIONAL ABU } \\
\text { DHABI(M) BHD }\end{array}$ & 1.9459 & 0.4207 & 0.0262 & 2.3928 & 21144.60 & 24 & 26 \\
$\begin{array}{l}\text { MIZUHO BANK (M) BHD } \\
\text { BNP PARIBAS (M) BHD }\end{array}$ & 1.5438 & 0.3155 & 0.0148 & 1.8741 & 30501.80 & 25 & 25 \\
$\begin{array}{l}\text { INDIA INTERN. BANK } \\
\text { (M) BHD }\end{array}$ & 1.2764 & 0.0130 & 0.0114 & 1.3007 & 5181.80 & 27 & 27 \\
\hline
\end{tabular}

In regard to the value added ranking, India International Bank surprisingly does not only design to be less efficient in used the VAIC as strategies to be more competitive but also inefficient in creating their value added. The mention bank has recorded on the VAIC and value added scored averagely at 1.3007 and RM5, 181.80 respectively and caused the bank to be ranked on the last position at number $27^{\text {th }}$. Other findings for Conventional and Islamic banks of the current study are portrays under Table 1.1 and 1.2. Based on the overall finding have practically discovered the human capital efficiency (HCE) as the major contributors on the total of VAIC scoring among the Malaysia banking sector. The reason is due to the facts that banking sector were primarily engaged in services sector which heavily relies on the customer service or banks' employees (human capital efficiency) which emphasize on the human mind and worker's knowledge (Mohiuddin et al., 2006). Prior on the current study is adding on another evidences towards the existing empirical findings that confirmed on human capital efficiency (HCE) that stand as primary leading factors and being a subject for the management in enhancing human capital to consider an effective alternatives for the banks in order to create more values for improving the efficiency level (Wang \& Chang, 2005).

\section{Conclusion}

These results are particularly encouraging and exposed to the real possibility that the investment in intellectual capital efficiency somehow in return provide a greater efficient and effective way.in creating the value added among the Malaysia banks. Thus, it would fostering the Malaysian banks in becoming more competitive within the market players as to continuously support the national economic performance (Bismuth \& Tojo, 2008). The finding consider an additional empirical evidences towards the existing literatures that postulated on the subject of interest within intellectual capital. Nevertheless, although the empirical finding for the current study revealed to be imperative however this is only to be consider as another footstep and process in setting a standards to face the greater challenge of the knowledge economy paradigm. On this note, Malaysia is currently transforming towards the knowledge-based economy due to the fact of challenges in globalization and the advancement of information and communication technologies that induced most of developing countries to move forwards into knowledge-based economy (Bhatiasevi, 2010) and enforced to transform from being input driven into knowledge-driven as for the ticket in achieving the vision of 2020 in becoming a developed nation (Abdulai, 2004; Bhatiasevi, 2010). As current study demonstrate on the finding that consistent to the previous work done by Chen et al., (2005) hence describe on the main finding render on the main components of intellectual capital that command 
on different values as opposed to the aggregate measure on the overall total VAIC scoring whereby the human capital is registered as the highest incidence of having the positive influences towards the efficiency performance rather than structural capital and capital employed. Therefore, highly recommend and suggest that investment and management of human capital is pivotal especially for the Malaysian banks technically in order to optimize their level of efficiency performance. On the other hand, to respond the advancement in technologies that could possibly replacing the human resource that may impact on the overall Malaysian banks in sustaining their long term survival, thus for that reason, the policy makers and management should not to lose sight on the standalone roles that contributed by one of the main components in intellectual capital namely human capital in influencing the efficiency performances of Malaysian banks as a whole. According to Becker (1964), although the technologies evolved and denominated the countries however, this is contributed only less in values to the countries as matter of fact, just only a number of skilled workers know how to control and use them. As for the alternatives to the policy makers and captains to take an initiative by considering their investment as well as to manage in human capital as for the single resources for optimizing the level of efficiency performance among the Malaysian banks.

Acknowledgment: This work was supported by the Ministry of Education, Malaysia and Universiti Malaysia Sarawak [grant numbers F01/FRGS/1607/2017].

\section{References}

Abdulai, D. (2004). Can Malaysia Transit into the K-Economy? Dynamic Challenges, Tough Choices, and the Next Phase. Malaysia: Pelanduk Publications Sdn Bhd.

Appuhami, B. R. (2007). The Impact of Intellectual Capital on Investors' Capital Gains on Shares. An Empirical Investigation of Thai Banking, Finance and Insurance Sector. International Management Review, 3(2), 14-25.

Ashton, R. H. (2005). Intellectual Capital and Value Creation. A Review Journal of Accounting Literature, 24, 53-134

Becker, G. S. (1964). Human Capital Theory: A Theoretical and Empirical Analysis with special Reference to Education. New York: Columbia University Press.

Belkaoui, A. R. (2003). Intellectual Capital and firm performance of US Multinational Firms. Journal of Intellectual Capital, 4, 215-26.

Bhatiasevi, V. (2010). The Race towards a Knowledge-Based Economy. A Comparative Study Between Malaysia and Thailand. International Journal of Business and Management, 5(1), 14 122.

Bismuth, A., \& Tojo, Y. (2008). Creating Value from Intellectual Assets. Journal of Intellectual Capital, 9(2), 228-245.

BontisN. (1998). Intellectual Capital. An Exploratory Study that Develops Measures and Models.

Management Decision, 36, 63-76.

Bontis, N. (2001). Assessing Knowledge Assets. A Review of the Models used to Measure Intellectual

Capital. International Journal of Management Reviews, 3(1), 41-60.

Chen, M. C., Cheng, S. J., \& Hwang, Y. (2005). An Empirical Investigation of the Relationship Between Intellectual Capital and Firms' Market Value and Financial Performance. Journal of 
INTERNATIONAL JOURNAL OF ACADEMIC RESEARCH IN BUSINESS AND SOCIAL SCIENCES Vol. 9, No. 6, June, 2019, E-ISSN: 2222-6990 @ 2019 HRMARS

intellectual capital, 6(2), 159-176.

Drucker, P. F. (1993). The Rise of the Knowledge Society (pp. 52-71). Washington, USA:Wilson Quarterly.

Edvinsson, L. (1997). Developing Intellectual Capital at Skandia. Long Range Planning, 30, 266-373.

Edvinsson, L., \& Malone, M. S. (1997). Intellectual Capital: The Proven Way to Establish Your Company's Real Value by Finding its Hidden Brainpower. NY: Harper Business, Piatkus.

Edvinsson, L. Sullivan, P. (1996). Developing a Model for Managing Intellectual Capital. European. Management Journal, 14, 356-364.

Firer, S., \& Mitchell Williams, S. (2003). Intellectual Capital and Traditional Measures of Corporate Performance. Journal of Intellectual Capital, 4(3), 348-360.

Goh, P. C., (2005). Intellectual Capital Performance of Commercial Banks in Malaysia. Journal of Intellectual Capital, 6, 385-396.

Guthrie, J. (2001). The Management, Measurement and the Reporting of Intellectual Capital. Journal of Intellectual Capital, 2, 27-41.

Ho, C. A., \& Williams, S. M. (2003). International Comparative Analysis of the Association Between Board Structure and the Efficiency of Value Added by a Firm from its Physical Capital and Intellectual Capital Resources. The International Journal of Accounting 28(4), 465-491.

Isanzu, J. N., (2016). The Relationship between Intellectual Capital and Financial Performance of Banks in Tanzania. Journal on Innovation and Sustainability, 7(1), 28-38.

Kale, P. Singh, H., \& Perlmutter, H. (2000). Learning and Protection of Proprietary Assets In Strategic Alliances: Building Relational Capital. Strategic Management Journal, 21(3), 217-237.

Kozak, M. (2011). Strategic Approach to Intellectual Capital Development in Regions. International Journal of Learning and Intellectual Capital, 8(1), 76-93.

Kubo, I., \& Saka, A. (2002). An Inquiry into the Motivations of Knowledge Workers in the Japanese Financial Industry. Journal of Knowledge Management, 6(3), 262-271.

Mavridis, D. G. (2004). The Intellectual Capital Performance of the Japanese Banking Sector. Journal of Intellectual capital, 5(1), 92-115.

Mohiuddin, M., Najibullah, S., \& Shahid, A. I. (2006). An Exploratory Study on Intellectual Capital Performance of the Commercial Banks in Bangladesh. The Cost and Management, 34(6), 4054.

Najibullah, S. (2005). An Empirical Investigation of the Relationship between Intellectual Capital and Firms' Market Value and Financial Performance. In Context of Bangladesh Commercial Bank. Bangladesh: Independent University.

Nik Maheran N. M., \& Md Khairu, (2009) .Intellectual Capital Efficiency and Firm's Performance. Study on Malaysian Financial Sectors. International Journal of Economics and Finance, 1(2), 206-212.

Porter, M. E. (1998). Clusters and the New Economics of Competition. Boston: Harvard Business Review. 76(6):77-90.

Prahalad, C. K., \& Ramaswamy, V. (2000). Co-opting Customer Competence. Harvard Business Review, 78(1), 79-90. 
INTERNATIONAL JOURNAL OF ACADEMIC RESEARCH IN BUSINESS AND SOCIAL SCIENCES

Vol. 9, No. 6, June, 2019, E-ISSN: 2222-6990 (C) 2019 HRMARS

Pulic, A. \& Bornemann, M. (1997). The Physical and Intellectual Capital of Austrian Banks. Retrieved from http://www.vaic-on.net

Pulic, A. (2004). Intellectual Capital. Does it Create or Destroy Value. Measuring Business Excellence, 8(1), 62-68.

Roos, G., \& Roos, J. (1997). Measuring your Company's Intellectual Performance. Long Range Planning, 30(3), 413-426.

Roslender, R., \& Fincham, R. (2004). Intellectual Capital Accounting in the UK. A Field Study Perspective. Accounting, Auditing and Accountability Journal, 17, 178-209.

Saengchan, S. (2008). The Role of Intellectual Capital in Creating Value in the Banking Industry. International Review of Business Research, 7, 157-169.

Sengge, P. (2010). Change Dance. Constant Change Challenges in Learning Organization. In A. Hosein \& S. Mosud (4th eds) Tehran: Aryana Research Group Pub.

Sledzik, K. (2013). The Intellectual Capital Performance of Polish Banks. An Application Of VAIC Model. Financial Internet Quarterly e-Finance, 9(2), 92-100.

Stahle, P., \& Bounfour, A. (2008). Understanding Dynamics of Intellectual Capital of Nations. Journal of Intellectual Capital, 9(2), 164-177

Stahle, P., Stahle, S., \& Aho, S. (2011). Value Added Intellectual Coefficient (VAIC). A Critical Analysis. Journal of Intellectual Capital, 12(4), 531-551.

Stewart, T. A. (1997). Intellectual Capital: The New Wealth of Organization. New York, USA: Bantam Doubleday Dell Publishing.

Tan, H. P. Plowman, D., \& Hancock, P. (2007). Intellectual Capital and Financial Returns of Companies. Journal of Intellectual Capital, 8, 76-95.

Tayles, M. Pike, R., \& Sofian, S. (2007). Intellectual Capital, Management Accounting Practices And Corporate Performance. Accounting, Auditing and Accountability Journal, 20, 522548

Viedma, Marti, J. M. (2000). La gestión Del conocimiento y Del Capital Intellectual. Internet, Retrieved from http://www. Gestióndelcapitalintellectual.com.

Wang, W. Y., \& Chang, C. (2005). Intellectual capital and Performance in Causal Models: Evidence from the Information Technology Industry in Taiwan. Journal of Intellectual Capital, 6(2), 222236.

Zeghal, D., \& Maaloul, A. (2010). Analyzing Value Added as Indicator of Intellectual Capital and its Consequences on Company Performance. Journal of Intellectual Capital, 11(1), 39-60. 